\title{
Comparison between the synthesis of gold nanoparticles with sodium citrate and sodium tetraboreto
}

\author{
Adilson R Prado ${ }^{1,2^{*}}$, Jairo P Oliveira ${ }^{3}$, Wanderson J Keijok ${ }^{3}$, Bárbara Altoé Milaneze 3 , Breno V Nogueira ${ }^{3}$, \\ Marco CC Guimarães ${ }^{3}$, Maria J Pontes ${ }^{1}$, Moises RN Ribeiro ${ }^{1}$ \\ From 5th Congress of the Brazilian Biotechnology Society (SBBIOTEC) \\ Florianópolis, Brazil. 10-14 November 2013
}

\section{Background}

With gold nanoparticles (AuNPs) is possible to develop nanoscale devices that can interact with chemical and biological systems. The phenomenon explored in these nanosystems is called Localized Surface Plasmon Resonance (LSPR), which promotes electromagnetic wave oscillation electronics on these small metallic structures. It is interesting to note that this resonance is directly linked to the size of the nanoparticles, the nature of the dielectric material and support environment where the device is being studied [1,2].

This work makes a comparison between results obtained in the synthesis of AuNP's reduction method using a Sodium Citrate $\left(\mathrm{Na}_{3} \mathrm{C}_{6} \mathrm{H}_{5} \mathrm{O}_{7}\right)$ and Sodium Borohydride $\left(\mathrm{NaBH}_{4}\right)$. Was expected to demonstrate the viability of these two reducing agents and highlight the potential differences obtained in each of the mechanisms. Since knowledge is the ability of stabilizing citrate ions and the strong reducing action of $\mathrm{NaBH}_{4}$ [3]. The dominance of this knowledge will provide the development of systems with particle size specific for various applications in biosensors.

\section{Methods}

In these experiments consisted initially in the preparation of the following aqueous solutions: $100 \mathrm{~mL}$ Tetrachloroauric Acid $\left(\mathrm{HAuCl}_{4}\right) 2.5 \times 10^{-4} \mathrm{M}, 5 \mathrm{~mL}$ of $1 \% \mathrm{NaBH}_{4}$ and $5 \mathrm{~mL}$ of $\mathrm{Na}_{3} \mathrm{C}_{6} \mathrm{H}_{5} \mathrm{O}_{7}$ also $1 \%$.

The synthesis of nanoparticles were carried out simultaneously with the reducing agents, for it was placing 50.0 $\mathrm{mL}$ of $\mathrm{HAuCl} 4$ solution in two Erlenmeyer and the

${ }^{1}$ Telecommunications Laboratory (LabTel), DEL/CT, Federal University of Espírito Santo (UFES), Vitória, ES, Brazil following adding agent reducing in agitation. The system with sodium citrate was put into a heating temperature of $65{ }^{\circ} \mathrm{C}$ with $\mathrm{NaBH}_{4}$ has not been heated. The reaction time for both was $25 \mathrm{~min}$, but the use of heating in half with $\mathrm{Na}_{3} \mathrm{C}_{6} \mathrm{H}_{5} \mathrm{O}_{7}$ was off to achieve 10 min of reaction. The procedure used here was based on literature data, with some adaptations [3].

The samples produced AuNP's had their optical properties assessed by UV-Vis spectrophotometry. The size and morphology of AuNP's were examined by Transmission Electron Microscopy (TEM) (JEM-1400, JEOL/ USA Inc.).

\section{Results and conclusion}

The UV-Vis spectrophotometry shows the absorption of the samples obtained in experiments, it is noted that the easy synthesis with $\mathrm{NaBH}_{4}$ did not generate nanoparticles with a reasonable size for the LSPR occur. Phenomenon responsible for the peak at $530 \mathrm{~nm}$ in the spectrum of sodium citrate $\left(\mathrm{Na}_{3} \mathrm{C}_{6} \mathrm{H}_{5} \mathrm{O}_{7}\right)$.

Due to capacity reduction of $\mathrm{NaBH}_{4}$ lot nuclei initiators nanoparticles were generated, but reduced in size. $\mathrm{Na}_{3} \mathrm{C}_{6} \mathrm{H}_{5} \mathrm{O}_{7}$ already has a good ability to stabilize, thus required temperature rise in the synthesis process to increase capacity reduction. Nuclei being formed ions favor the stabilization phase of growth, thus generating nanostructures favorable process RPSL to $530 \mathrm{~nm}$.

\section{Acknowledgements}

Laboratory of Cellular Ultrastructure Carlos Alberto Redins (LUCCAR)-CCS/ UFES. Brazilian Ministry of Science and Technology (CNPq Grant 483036/ 2011-0) and The Ministry of Science and Technology (MCTI/FINEP/CT-INFRA grant PROINFRA 01/2006).
Full list of author information is available at the end of the article

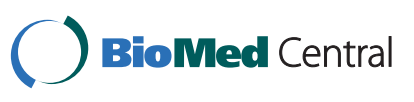

Attribution License (htp://creativecommc in any medium, provided the original work is properly cited. The Creative Commons Public Domain Dedication waiver (http://creativecommons.org/publicdomain/zero/1.0/) applies to the data made available in this article, unless otherwise stated. 


\section{Authors' details}

'Telecommunications Laboratory (LabTel), DEL/CT, Federal University of Espírito Santo (UFES), Vitória, ES, Brazil. ${ }^{2}$ Federal Institute of the Espírito Santo (IFES), Vitória, ES, Brazil. " ${ }^{3}$ Laboratory Cellular Ultrastructure (CCS), Federal University of Espírito Santo (UFES), Vitória, ES, Brazil.

Published: 1 October 2014

\section{References}

1. Tinguely JC, Sow I, Leiner C, Grand J, Hohenau A, Felidj N, Aubard J, Krenn JR: Gold Nanoparticles for Plasmonic Biosensing: The Role of Metal Crystallinity and Nanoscale Roughness. BioNanoscience 2011, 1:128-135

2. Morones JR, Elechiguerra JL, Camacho A, Holt K, Kouri JB, Ramirez JT, Yacaman MJ: The bactericidal effect of silver Nanoparticles. Nanotechnology 2005, 16:2346-2353.

3. Melo JRMA, Santos LSS, Gongalves MC, Nogueira AF: Preparação de Nanopartículas de Prata e Ouro: Um Método Simples para a Introdução da Nanociência em Laboratório de Ensino. Quím Nova 2012. 35:1872-1878.

doi:10.1186/1753-6561-8-S4-P252

Cite this article as: Prado et al: Comparison between the synthesis of gold nanoparticles with sodium citrate and sodium tetraboreto. BMC Proceedings 2014 8(Suppl 4):P252.

\section{Submit your next manuscript to BioMed Central} and take full advantage of:

- Convenient online submission

- Thorough peer review

- No space constraints or color figure charges

- Immediate publication on acceptance

- Inclusion in PubMed, CAS, Scopus and Google Scholar

- Research which is freely available for redistribution

Submit your manuscript at www.biomedcentral.com/submit 